\title{
Impact of low vision services on the quality of life of low vision patients in Ghana
}

\begin{tabular}{|c|c|}
\hline $\begin{array}{l}\text { Authors: } \\
\text { Godwin O. Ove } \\
\text { Harriette Osa } \\
\text { Ralph E.U. Ak } \\
\text { James Addy } \\
\text { Elizabeth O. O }\end{array}$ & $\begin{array}{l}\text { nseri-Ogbomo } \\
\text { o-Agyei }{ }^{1,2} \\
\text { oalaba }{ }^{1} \\
\text { venseri }^{4}\end{array}$ \\
\hline $\begin{array}{l}\text { Affiliations: } \\
{ }^{1} \text { Department } \\
\text { University of }\end{array}$ & $\begin{array}{l}\text { of Optometry, } \\
\text { Benin, Nigeria }\end{array}$ \\
\hline $\begin{array}{l}{ }^{2} \text { Department } \\
\text { University of } \\
\text { Ghana }\end{array}$ & $\begin{array}{l}\text { of Optometry, } \\
\text { Cape Coast, }\end{array}$ \\
\hline $\begin{array}{l}{ }^{3} \text { Ophthalmolo } \\
\text { Regional Hosk }\end{array}$ & $\begin{array}{l}\text { gy Unit, Eastern } \\
\text { ital, Ghana }\end{array}$ \\
\hline $\begin{array}{l}{ }^{4} \text { Central Hosp } \\
\text { Nigeria }\end{array}$ & ital, Warri, \\
\hline $\begin{array}{l}\text { Correspondin } \\
\text { Godwin Oven } \\
\text { ovenseriogbo }\end{array}$ & $\begin{array}{l}\text { g author: } \\
\text { seri-Ogbomo, } \\
\text { mo@gmail.com }\end{array}$ \\
\hline $\begin{array}{l}\text { Dates: } \\
\text { Received: } 08 \\
\text { Accepted: } 17 \\
\text { Published: } 30\end{array}$ & $\begin{array}{l}\text { uly } 2014 \\
\text { Nov. } 2014 \\
\text { Mar. } 2016\end{array}$ \\
\hline $\begin{array}{l}\text { How to cite th } \\
\text { Ovenseri-Ogb } \\
\text { Osafo-Agyei H } \\
\text { Addy J, Ovens } \\
\text { of low vision s } \\
\text { quality of life } \\
\text { patients in Gh } \\
\text { Eye Health. } 20 \\
\text { http://dx.doi. } \\
\text { aveh.v75i1.19 }\end{array}$ & $\begin{array}{l}\text { is article: } \\
\text { omo GO, } \\
\text {, Akpalaba REU, } \\
\text { eri EO. Impact } \\
\text { ervices on the } \\
\text { of low vision } \\
\text { ana. Afr Vision } \\
16 ; 75(1) \text {, a19. } \\
\text { org/10.4102/ }\end{array}$ \\
\hline $\begin{array}{l}\text { Copyright: } \\
\text { (c) 2016. The } A \\
\text { Licensee: AOS } \\
\text { is licensed un } \\
\text { Creative Comr } \\
\text { Attribution Lic }\end{array}$ & $\begin{array}{l}\text { uthors. } \\
\text { IS. This work } \\
\text { ler the } \\
\text { nons } \\
\text { ense. }\end{array}$ \\
\hline Read online: & \\
\hline 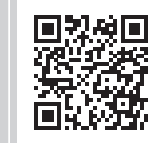 & $\begin{array}{l}\text { Scan this QR } \\
\text { code with your } \\
\text { smart phone or } \\
\text { mobile device } \\
\text { to read online. }\end{array}$ \\
\hline
\end{tabular}

Authors:

Harriette Osafo-Agyei ${ }^{3}$

Ralph E.U. Akpalaba

James Addy

Affiliations:

${ }^{1}$ Department of Optometry,

${ }^{2}$ Department of Optometry, University of Cape Coast,

${ }^{3}$ Ophthalmology Unit, Eastern

${ }^{4}$ Central Hospital, Warri,

Nigeria

Godwin Ovenseri-Ogbomo,

Dates:

Accepted: 17 Nov. 2014

Addy J, Ovenseri EO. Impact

of low vision services on the quality of life of low vision

http://dx.doi.org/10.4102/

Copyright:

(c) 2016. The Authors.

is licensed under the

Creative Commons

Attribution License.

mobile device

to read online.
Patients' perspectives on the impact of clinical interventions have been recognised as critical elements in patient care. Quality-of-life instruments are designed to measure these perspectives. We used the National Eye Institute's 25-item Visual Function Questionnaire (NEI VFQ) to measure the impact of optical low vision devices on the quality of life of 22 low vision patients who obtained and were using low vision devices from a secondary low vision clinic in the Eastern Region, Ghana. The study employed a pre- and post-intervention technique. We found statistically significant improvements in measured visual acuity and NEI VFQ scores in 8 of the 10 domains evaluated. We conclude that optical low vision devices have a positive impact on the quality of life of low vision patients in Ghana.

\section{Introduction}

Efforts have been made to implement programmes to eradicate preventable blindness by the year 2020. ${ }^{1}$ Low vision is one of the problems being targeted by the Vision 2020 programme. Individuals are said to have low vision if, after surgical and medical treatment and refractive correction, the individual has a distance visual acuity of 6/18. In many developing countries, there is a paucity of low vision services amongst eye care providers. Many reasons have been suggested for this paucity. ${ }^{2,3,4}$ A large number of eye care providers consider low vision services to be time-consuming, and some have a poor perception of the impact of rehabilitation services on the quality of life of low vision patients.

The effects of visual impairment on the individual, family and community have been well documented, ${ }^{2,5}$ and include visual, functional, psychological, social and economic consequences. These effects on the individual include limitations in performing certain tasks that require vision, and in educational, occupational and recreational activities. ${ }^{6,7,8,9,10,11}$ These limitations tend to reduce the quality of life of the individual affected by low vision. There is the additional psychological consideration of not being able to care for oneself and/or dependants. Stevenson et al. ${ }^{12}$ have reported that the ability to care for oneself or dependants is related to self-reported visual function and quality of life.

Quality of life measures the impact of a disease on the affected individual. The measures have also been applied to determine the influence of medical interventions on disease processes. Several quality of life instruments have been developed. Whilst the majority measure the impact of the disease on the total health of the individual (e.g. the health-related quality of life [HRQoL] questionnaire), others are organ specific, such as the National Eye Institute Visual Function Questionnaire (NEI VFQ). The 25-item NEI VFQ has been validated ${ }^{13}$ and found useful in measuring the impact of visual impairment on the quality of life of the individual affected.

Low vision services encompass assistance offered to individuals who have some residual vision through the use of low vision devices (LVDs), training in the effective use of residual vision, and advice on environmental modification to make the environment more accessible to patients with low vision. Such services also link eye care with education and rehabilitation services to ensure a comprehensive eye care service. ${ }^{14}$ Success of low vision services has been defined as reducing the level of difficulty in performing a visual task or goal..$^{15}$ Various authors have advocated in addition that the effectiveness of low vision rehabilitation services be measured in terms of improvement in a person's quality of life. . $^{16,17}$ Traditionally, the outcomes of low vision services were objectively measured through improvements in tests of visual function (such as visual acuity). ${ }^{18,19}$ However, studies ${ }^{15,16}$ have indicated that mere improvement in clinically measured visual acuity and other visual function tests does not adequately determine the success or effectiveness of low vision services. It has long been established that visual acuity measurements in the clinic do not correlate well with the actual performance of low vision patients, following rehabilitation services; ${ }^{19}$ this is because of 
differences between the clinical setting where the visual acuity is measured and the patients' environment (e.g. differences in contrast and illumination levels). Moreover, several factors beyond visual acuity and other visual function test scores affect the quality of life of individuals with low vision. ${ }^{11}$

Consequently, there is a general consensus that patient perspectives on the utility of devices and other rehabilitation interventions be considered in measuring the effectiveness of low vision services. In a review of the outcome of low vision rehabilitation, Stelmack ${ }^{17}$ concluded that self-reported quality of life is a significant measure of the impact of low vision rehabilitation. Therefore, subjective reports of less difficulty in performing visual tasks and the attendant sociopsychological effects are more appropriate in measuring the outcomes of low vision services.

To measure the impact of low vision rehabilitation, several instruments have been developed that use subjective responses from patients. These include the 48-item Veterans Affairs Low Vision Visual Function Questionnaire (VA LV VFQ), ${ }^{20,21}$ the Low Vision Quality of Life Questionnaire (LVQOL) ${ }^{22}$ and the Impact of Vision Impairment (IVI) Questionnaire. ${ }^{23}$ These instruments were designed to measure the impact of low vision and other eye diseases on the quality of life of affected subjects. By comparing pre-rehabilitation and postrehabilitation responses from patients, the impact of low vision interventions can be measured using visual function questionnaires. We used the NEI VFQ to assess the impact of low vision services on the quality of life of low vision patients attending a secondary low vision clinic in Koforidua, Ghana.

\section{Method}

We conducted a pre- and post-low vision intervention interview of patients visiting the Low Vision Clinic of the Eastern Regional Hospital, Koforidua. A pre- and post-rehabilitation method was employed in measuring the outcome of low vision rehabilitation in a number of research studies. ${ }^{16,24,25,26}$ A non-probabilistic sampling technique was employed in our study because (1) it was operationally difficult to obtain a random sample of patients obtaining low vision services from the centre concerned, (2) the inclusion criteria employed in the study (meeting World Health Organization [WHO] criteria $^{27}$ for low vision [i.e. best corrected visual acuity of less than $6 / 18$ to light perception, visual field of less than $10^{\circ}$ from the point of fixation, the subject should be able to use vision for planning and execution of tasks or potentially able to do so]) meant that only a few participants would be recruited if we were to have employed random sampling and (3) the low uptake of low vision services would have also led to a low sample size, thus reducing the effect size.

All the patients aged 14 years and above presenting for low vision services who met the inclusion criteria as per the WHO definition of low vision were interviewed using the 25 item NEI VFQ. Three months after accessing the low vision service and obtaining a LVD, the questionnaire was re-administered to those who were using their devices. A total of 62 participants completed the questionnaire prior to accessing the low vision service. Of these, 25 (40.3\%) participants obtained optical LVDs after the low vision assessment. At follow-up interview, $22(88 \%)$ of these participants were available for interviews.

\section{Ethical consideration}

Ethical approval to conduct the study was obtained from the Department of Optometry, University of Cape Coast, Ghana. The study was also conducted in accordance with the Declaration of Helsinki on the use of human subjects in medical research. Eligible participants gave informed consent before participating in the study.

\section{Data analysis}

Participants' responses were scored using the accompanying manual ${ }^{28}$ to the 25 -item NEI VFQ. They were classified into 10 subscales as provided in the manual. Paired $t$-tests were used to compare the scores before and after low vision intervention, and appropriate tables and charts were used to report the pertinent findings of the study.

\section{Results \\ Participants}

A total of 62 patients presenting for low vision services from February 2011 to April 2012 were enlisted for the study. They comprised $40(64.5 \%)$ male subjects and $22(35.5 \%)$ female subjects. They were interviewed at presentation and administered the questionnaire. Three months after low vision assessment, 25 (40.3\%) had obtained their LVDs. Of these subjects, 22 were available for interviews to assess the impact of using LVDs on their quality of life. Table 1

TABLE 1: Demographics of the participants with age group indicated in years $(N=62)$.

\begin{tabular}{|c|c|c|c|c|c|c|c|c|c|c|c|c|}
\hline \multirow[t]{3}{*}{ Age group } & \multicolumn{6}{|c|}{ Initial presentations } & \multicolumn{6}{|c|}{ Low vision devices users } \\
\hline & \multicolumn{2}{|c|}{ Male } & \multicolumn{2}{|c|}{ Female } & \multicolumn{2}{|c|}{ Total } & \multicolumn{2}{|c|}{ Male } & \multicolumn{2}{|c|}{ Female } & \multicolumn{2}{|c|}{ Total } \\
\hline & $n$ & $\%$ & $n$ & $\%$ & $n$ & $\%$ & $n$ & $\%$ & $n$ & $\%$ & $n$ & $\%$ \\
\hline $11-30$ & 13 & 32.5 & 11 & 50.0 & 24 & 38.7 & 6 & 42.9 & 7 & 87.5 & 13 & 59.1 \\
\hline $31-50$ & 2 & 5.0 & 1 & 4.5 & 3 & 4.8 & 0 & $0.0)$ & 0 & 0.0 & 0 & 0.0 \\
\hline $51-70$ & 13 & 32.5 & 7 & 31.8 & 20 & 32.3 & 4 & 28.6 & 1 & 12.5 & 5 & 22.7 \\
\hline $71-90$ & 11 & 27.5 & 3 & 13.6 & 14 & 22.6 & 4 & 28.6 & 0 & 0.0 & 4 & 18.2 \\
\hline $91-110$ & 1 & 2.5 & 0 & 0.0 & 1 & 1.6 & 0 & 0.0 & 0 & 0.0 & 0 & 0.0 \\
\hline Mean age & 52.95 & - & 40.68 & - & 48.60 & - & 47.57 & - & 23.38 & - & 28.77 & - \\
\hline s.d. & 26.60 & - & 26.00 & - & 26.83 & - & 29.19 & - & 19.10 & - & 28.13 & - \\
\hline Total & 40 & 100.0 & 22 & 100.0 & 62 & 100.0 & 14 & 100.0 & 8 & 100.0 & 22 & 100.0 \\
\hline
\end{tabular}




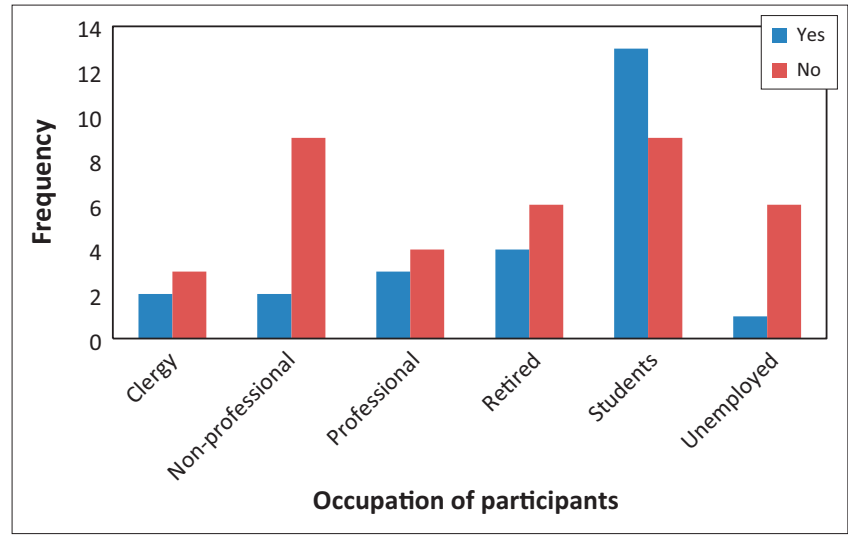

FIGURE 1: Distribution of occupation of participants showing the proportion of those who obtained their devices and those who did not obtain a low vision device $(N=62)$.

TABLE 2: Category of visual impairment.

\begin{tabular}{lccccc}
\hline Category $\dagger$ & \multicolumn{2}{c}{ Before low vision assessment } & & \multicolumn{2}{c}{ After low vision assessment } \\
\cline { 2 - 3 } \cline { 5 - 6 } & $\boldsymbol{n}$ & $\mathbf{\%}$ & & $\boldsymbol{n}$ & $\%$ \\
\hline Moderate & 32 & 51.6 & & 46 & 74.2 \\
Severe & 24 & 38.7 & & 14 & 22.6 \\
Profound & 6 & 9.7 & & 2 & 3.2 \\
\hline Total & $\mathbf{6 2}$ & $\mathbf{1 0 0 . 0}$ & & $\mathbf{6 2}$ & $\mathbf{1 0 0 . 0}$ \\
\hline
\end{tabular}

$\dagger$, Based on World Health Organization category of visual impairment.

presents demographic characteristics of the 62 study participants, and Figure 1 the participants' occupation categories.

\section{Visual acuity}

The distance visual acuity in the better seeing eye of the 62 participants before low vision intervention ranged from $0.60-1.68 \log$ MAR with a mean visual acuity of 1.04 (s.d. $=0.26)$. After low vision assessment, the distance visual acuity of the 62 participants ranged from $0.40-1.68$ $\log$ MAR with a mean of 0.83 (s.d. $=0.28$ ). This change represented a visual acuity improvement of $0.21 \mathrm{log}$ units (about two rows of letters on the $\log$ MAR chart). The difference between visual acuity before and after assessing low vision service was significant $(p<0.0001)$. There was a corresponding shift in the category of visual impairment following low vision assessment (Table 2).

\section{Impact of low vision services}

Participants who obtained and were reportedly using their LVDs for 3 months reported improvements in the various tasks assessed (Figure 2). Twenty-five (40.3\%) participants had extreme difficulty performing visionrelated tasks before assessing LVDs. Of the 22 participants who were interviewed after obtaining their devices, 13 (59.1\%) reported extreme difficulty performing visionrelated tasks at presentation. After using their devices, only $2(9.1 \%)$ reported extreme difficulty for the same vision-related tasks $\left(\chi^{2}=12.24, p=0.00047\right)$. There was also an increase amongst subjects reporting little or no difficulty performing these tasks after obtaining and
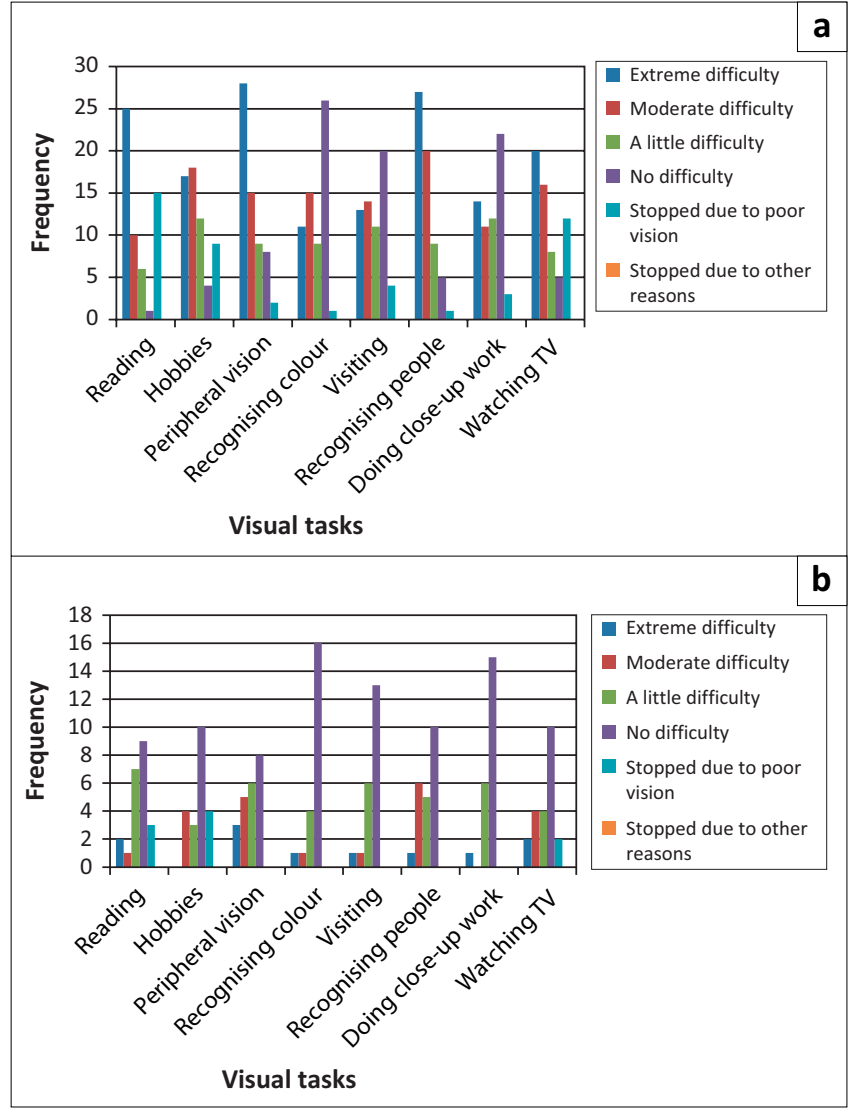

FIGURE 2: Difficulty performing task: (a) before low vision assessment $(N=62)$, (b) after obtaining and using low vision devices for 3 months $(N=22)$.

TABLE 3: Comparison of effect of low vision devices.

\begin{tabular}{lcccccc}
\hline Subscale & $\boldsymbol{n}$ & $\begin{array}{c}\text { Before } \\
\text { LVD mean }\end{array}$ & s.d. & $\begin{array}{c}\text { After LVD } \\
\text { mean }\end{array}$ & s.d. & $\boldsymbol{p}$ \\
\hline General vision & 22 & 46.33 & 16.78 & 68.18 & 15.93 & $<0.0001$ \\
Near vision & $21 \dagger$ & 54.37 & 20.52 & 76.59 & 27.08 & $<0.0001$ \\
Distance vision & 22 & 46.59 & 25.05 & 73.86 & 25.85 & $<0.0001$ \\
Peripheral vision & 22 & 56.82 & 28.01 & 71.59 & 27.05 & 0.002 \\
Colour vision & 22 & 84.09 & 23.84 & 89.77 & 19.91 & 0.096 \\
Ocular pains & 22 & 67.05 & 28.22 & 72.73 & 18.76 & 0.348 \\
Role difficulty & 22 & 39.77 & 20.28 & 62.50 & 20.77 & $<0.0001$ \\
Dependency & 22 & 51.36 & 23.10 & 62.27 & 22.87 & 0.001 \\
Mental health & 22 & 46.59 & 21.80 & 60.23 & 18.75 & 0.002 \\
Social function & 22 & 72.73 & 31.73 & 128.36 & 195.47 & $<0.0001$ \\
\hline
\end{tabular}

LVD, low vision device; s.d., standard deviation.

$\dagger$, One subject had stopped performing more than one of the activities in the near vision subscale.

using their LVDs (3 [13.6\%] vs. 16 [72.7\%], $\chi^{2}=15.65$, $p=0.0001)$.

Quality of life improved amongst those who had obtained devices. There was a significant improvement in 8 of the 10 subscales investigated following low vision services (Table 3). Colour vision $(p=0.096)$ and ocular pains ( $p=0.348)$ were not significantly affected by low vision services, as reported by study participants.

The change in 10 domains is shown in Figure 3. Greatest improvement was reported in the social function domain, with a $76.6 \%$ improvement in score following low vision intervention. 


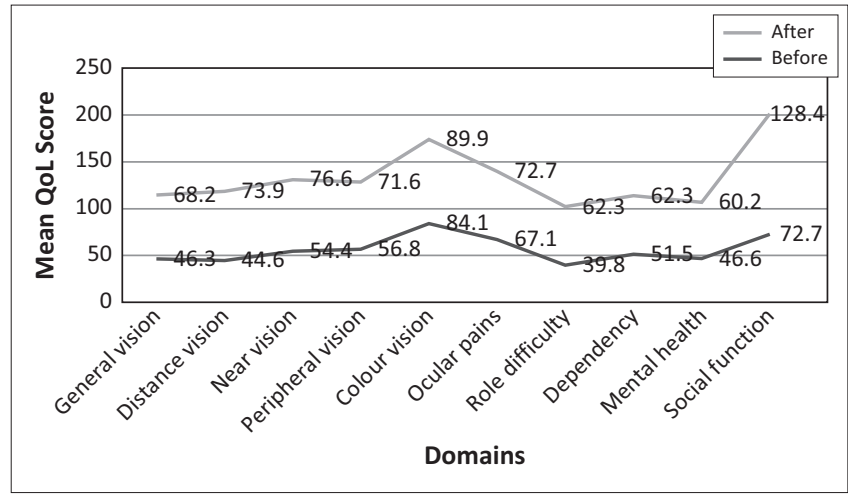

FIGURE 3: Change in quality of life measures after low vision intervention (with optical low vision devices).

\section{Discussion}

The mean age of participants in this study is low (i.e. younger) compared with similar studies..$^{25,26,29,30}$ The study's relatively younger age group may reflect the poor and uncoordinated nature of low vision services in Ghana. Parents and guardians of children and young adults with low vision may tend to assist their wards in obtaining LVDs because the effect of reduced vision on academic studies is immediately felt by children and their parents. Elderly subjects with low vision may also have other chronic health conditions requiring the attention of caregivers. In Ghana, low vision services are not covered by the National Health Insurance Scheme and consequently individuals have to pay for these services themselves. Generally the elderly, who are reported to be most affected by low vision, ${ }^{31,32,33}$ cannot afford these services. Another factor may be the population dynamics in Ghana: life expectancy has only recently been reported $^{34}$ to be 64.2 years, up from 57 years. The mean age of subjects obtaining LVDs is also considerably low at $28.77 \pm 28.13$ years. Given the literacy level in Ghana, reported $^{35}$ to be $71.5 \%$ in 2012, we can only suggest that those who obtained LVDs were more likely to be educated, with a desire to be able to read, which is further supported by the fact that $13(59.1 \%)$ of those who had obtained the LVDs in this study were students and aged $\leq 30$ years. The uptake of LVDs after accessing low vision services was not influenced by the occupation of the patients, although $66 \%$ of those who obtained their LVDs after assessment were either students or professionals $\left(\chi^{2}=2.22, p=0.1364\right)$.

\section{Impact of low vision services}

Traditionally, clinical improvement in visual acuity is used as a measure of a successful low vision service. There was a significant improvement in measured visual acuity following low vision assessment, which was further evidenced by a shift in the category of visual impairment following low vision assessment (Table 2). There was an increase in the proportion of participants with moderate low vision with a corresponding decrease in the proportion of those with severe and profound low vision.

As stated in the introduction, patients' perspectives are important in assessing the impact of low vision services beyond improvements in clinically measured visual acuity. In the present study, whereas $4.5 \%$ of the 22 participants (i.e. $1.6 \%$ of the initial 62 participants) reported not having any difficulty with reading at presentation, $41 \%$ of those 22 who were using their devices reported not having difficulty reading. Similarly, the proportion of those who had extreme difficulty reading was $59.1 \%$ at presentation compared with $9.1 \%$ after using their device. A smaller proportion of respondents who had been using their devices for 3 months reported extreme difficulty performing visual-related tasks. There was also a marked increase in the proportion of those reporting no difficulty performing visual tasks after obtaining and using LVDs for 3 months (Figure 2).

Respondents reported significant improvement in 8 of the 10 subscales. These were general vision, near vision, distance vision, peripheral vision, role difficulty, dependency, mental health and social function. No significant improvements in colour vision or ocular pains were reported, which is indicative of the fact that provision of LVDs does not markedly affect these domains. The most significant effect of low vision services was reported in the social function domain, which gives credence to the fact that, beyond mere visual functioning, there are other aspects of life of the low vision patient that are affected by low vision intervention.

From our investigations, we suggest that the quality of life of people with low vision is improved by LVDs. It should be noted, however, that the present study evaluated the impact that the intervention of optical LVDs had on the quality of life of patients with low vision. It should be expected that when other aspects of low vision intervention including environmental modification, orientation and mobility training are evaluated, the overall impact might be even more marked.

\section{Acknowledgements}

The authors thank the African Vision Research Institute for financial assistance with publishing page fees.

\section{Competing interests}

The authors declare that they have no financial or personal relationships which may have inappropriately influenced them in writing this article.

\section{Authors' contributions}

G.O.O-O. (University of Benin) study conception, study design, data analysis, initial draft of manuscript. H.O-A. (Eastern Regional Hospital) study conception, data collection, reviewed draft manuscript. R.E.U.A. (University of Benin) data analysis, reviewed draft manuscript. J.A. (Eastern Regional Hospital) study conception, data collection. E.O.O. (Central Hospital) data analysis, draft manuscript. 


\section{References}

1. World Health Organization. Vision 2020: The right to sight: Global initiative for the elimination of avoidable blindness. Action Plan 2006 - 2011. Geneva: World Health Organization, 2007.

2. Centre for Eye Research. Focus on low vision. Melbourne: Centre for Eye Research, 2007.

3. Taylor HR. Eye care for the future (The Weisenfeld Lecture). Invest Ophthalmol Vis Sci. 2003;44:1413-1418. http://dx.doi.org/10.1167/iovs.02-0571

4. Okoye OI, Aghaji AE, Umeh RE. Barriers to the provision of clinical low-vision services among ophthalmologists in Nigeria. Vis Imp Res. 2007;9:11-17. http://dx.doi.org/10.1080/13882350701198702

5. Overbury O, Wittich W. Barriers to low vision rehabilitation: The Montreal Barriers Study. Invest Ophthalmol Vis Sci. 2011;51:8933-8938. http://dx.doi.org/10.1167/ iovs.11-8116

6. Rahi JS, Cable N. Severe visual impairment and blindness in children in the UK. Lancet. 2003;362:1359-1365. http://dx.doi.org/10.1016/S0140-6736(03) 14631-4

7. Wang JJ, Mitchell P, Smith W. Vision and low self-rated health: The Blue Mountains Eye Study. Invest Ophthalmol Vis Sci. 2000;41:49-54.

8. McCarthy CA, Nanjan MB, Taylor HR. Vision impairment predicts five-year mortality Br J Ophthalmol. 2001;85:322-326. http://dx.doi.org/10.1136/bjo.85.3.322

9. West SK, Munoz B, Rubin GS, et al. Function and visual impairment in a populationbased study of older adults. Invest Ophthalmol Vis Sci. 1997;38:72-82.

10. Kekelis LS, Sacks SZ. Mainstreaming visually impaired children into regular educational programs: The effects of visual impairment on childrens's social interactions with peers. In: SZ Sacks, LS Kekelis, RJ Gaylord-Ross. The development of social skills by visually impaired children. San Francisco: San Francisco State University, 1988.

11. O'Connor P, Keefe J. Focus on low vision. Melbourne: Centre for Eye Research, 2007; pp. 16-7.

12. Stevenson MR, Hart PM, Montgomery A-M, McCulloch DW, Chakravarthy $U$. Reduced vision in older adults with age related macular degeneration interferes with ability to care for self and impairs role as carer. Br J Ophthalmol. 2004;88:1125-1130. http://dx.doi.org/10.1136/bjo.2003.032383

13. Mangione CM, Lee PP, Gutierrez PR, et al. Development of the 25 -Item National Eye Institute Visual Function Questionnaire. Arch Ophthalmol. 2001;119: 1050-1058. http://dx.doi.org/10.1001/archopht.119.7.1050

14. Minto H, Awan H. Establishing low vision services at secondary level. Comm Eye Health. 2004;17:5.

15. Massof RW. A system model for low vision rehabilitation. I. Basic concepts. Optom Vis Sci. 1995;72:72-76. http://dx.doi.org/10.1097/00006324-199510000-00005

16. Stelmack JA, Stelmack TR, Massof RW. Measuring low-vision rehabilitation outcomes with the NEI VFQ-25. Invest Ophthalmol Vis Sci. 2002;43:2859-2868.

17. Stelmack JA. Quality of life of low-vision patients and outcome of low-vision rehabilitation. Optom Vis Sci. 2001;128:335-342. http://dx.doi.org/10.1097/ 00006324-200105000-00017

18. Nilsson UL, Nilsson SE. Rehabilitation of the visually handicapped with advanced macular degeneration: A follow-up at the Low Vision Clinic, Department of
Ophthalmology, University of Linkoping. Doc Ophthalmol. 1986;62:345-367. http://dx.doi.org/10.1007/BF00168266

19. Raasch TW, Leat SJ, Kleinstein RN, Bullimore MA, Cutter GR. Evaluating the value of low-vision services. J Am Optom Assoc. 1997;68:287-295.

20. Stelmack JA, Szlyk JP, Stelmack TR, et al. Psychometric properties of the Veterans Affairs Low-Vision Visual Functioning Questionnaire. Invest Ophthtalmol Vis Sci. 2004;45:3919-3928. http://dx.doi.org/10.1167/iovs.04-0208

21. Szlyk JP, Stelmack J, Massof RW, et al. Performance of the veterans affairs low vision visual functioning questionnaire. J Vis Impair Blind. 2004;98(5):261-275.

22. Wolffsohn JS, Cochrane AL. Design of the low vision quality-of-life questionnaire (LVOOL) and measuring the outcome of lowvision rehabilation. Am J Ophthalmol. 2000;130:793-802. http://dx.doi.org/10.1016/S0002-9394(00)00610-3

23. Lamoureux EL, Pallant JE, Pesudovs K, Rees G, Hassell JB, Keefe JE. The impact of the Vision Impairment Questionnaire: An assessment of its domain structure using confirmatory factor analysis and Rasch analysis. Invest Ophthalmol Vis Sci. 2007; 48:1001-1006. http://dx.doi.org/10.1167/iovs.06-0361

24. Stelmack JA, Szlyk JP, Stelmack TR, Demers-Turco P, Williams RT, Moran D, Massof RW. Measuring outcomes of vision rehabilitation with the Veterans Affairs Low Vision Functioning Questionnaire. Invest Ophthalmol Vis Sci. 2006;47:3253-3261. Vision Functioning Questionnaire. Invest
$\mathrm{http}: / / \mathrm{dx}$.doi.org/10.1167/iovs.05-1319

25. Lamoureux EL, Pallant JF, Pesudovs K, Rees G, Hassell JB, Keffe JE. The effectiveness of low-vision rehabilitation on participation in daily living and quality of life. Invest Ophthalmol Vis Sci. 2007;48:1476-1482. http://dx.doi.org/10.1167/iovs.06-0610

26. Hinds A, Sinclair A, Park J, Suttie A, Paterson H, Macdonald M. Impact of an interdisciplinary low vision service on the quality of life of low vision patients. Br J Ophthalmol. 2003;87:1391-1396. http://dx.doi.org/10.1136/bjo.87.11.1391

27. World Health Organization. Magnitude of low vision in children. WHO/PBL/93.27. Geneva: World Health Organization, 1992.

28. The National Eye Institute 25-Item Visual Function Questionnaire (VFQ-25). [cited 10 February 2012]. Available from: http://www.rand.org

29. Ryan B, Court H, Margrain TH. Measuring low vision service outomes: Rasch analysis of seven-item National Eye Institute Visual Function Questionnaire. Opt Vis Sci. 2008;85:112-121. http://dx.doi.org/10.1097/OPX.0b013e31816225dc

30. van Rens GH, Chmielowski RJ, Lemmens WA. Results obtained with low vision aids. A retrospective study. Doc Ophthalmol. 1991;78:205-210. http://dx.doi. org/10.1007/BF00165682

31. Department of Veterans Affairs. Visual impairment and blindness. Washington Department of Veterans Affairs, 2002.

32. Salive ME, GuralnikJ, Christen W, Glynn RJ, Colsher P, Ostfeld AM. Functional blindness and visual impairment in older adults from three communities. Ophthalmol. 1992;99:1840-1847. http://dx.doi.org/10.1016/S0161-6420(92)31715-4

33. Entekume G, Patel J, Sivasubramaniam S, et al. Prevalence, causes and risk factors for functional low vision in Nigeria: Results from the National Survey of Blindness and Visual Impairment. Invest Ophthalmol Vis Sci. 2011;52:6714-6719. http:// dx.doi.org/10.1167/iovs.11-7293

34. United Nations Development Programme. Human development report Sustainability and equity: A better future for all. New York: Palgrave MacMillan, 2011.

35. United Nations Children's Fund. At a glance: Ghana. [cited 14 May 2014]. Available from: http://www.unicef.org/infobycountry/ghana_statistics.html 